\title{
Nursing students facing moral distress: strategies of resistance
}

\author{
Estudantes de enfermagem diante de sofrimento moral: estratégias de resistência \\ Estudiantes de enfermería ante el sufrimiento moral: estrategias de resistencia
}

\section{Simoní Saraiva Bordignon', Valéria Lerch Lunardi', Edison Luiz Barlem', Rosemary Silva da Silveira', Flávia Regina Ramos", Graziele de Lima Dalmolin"', Jamila Geri Tomaschewski Barlem'}

' Universidade Federal do Rio Grande. Rio Grande, Rio Grande do Sul, Brazil.

"Universidade Federal de Santa Catarina, Department of Nursing. Florianópolis, Santa Catarina, Brazil.

"I' Universidade Federal de Santa Maria, Health Sciences Center. Santa Maria, Rio Grande do Sul, Brazil.

How to cite this article:

Bordignon SS, Lunardi VL, Barlem EL, Silveira RS, Ramos FR, Dalmolin GL, et al. Nursing students facing moral distress: strategies of resistance. Rev Bras Enferm [Internet]. 2018;71(Suppl 4):1663-70. [Thematic issue:

Education and teaching in Nursing] DOI: http://dx.doi.org/10.1590/0034-7167-2017-0072

\section{Submission:07-21-2017_Approval:03-14-2018}

\begin{abstract}
Objective: To understand the resistance strategies adopted by undergraduate students in nursing, faced with situations of moral distress (MD). Method: Qualitative research, developed in three universities in the south of Brazil, two federal and one private, with 21 undergraduate students in nursing from December 2015 to February 2016; the data was submitted to the discursive textual analysis and Foucauldian theoretical reference. Results: Students resisting demonstrate a sense of self-preservation and moral empowerment. Moreover, non-resistance initiatives are related to the fear of possible sanctions. Thus, by resisting or not, students may experience both positive and negative repercussions. Final considerations: By resisting, students aim to defend what they believe to be right, demonstrating their moral empowerment in the face of their moral distress. However, the exercise of disciplinary power seems to contribute to their moral fragilization, making it difficult to implement resistance strategies.

Descriptors: Nursing Students; Nursing Education; Power; Moral; Ethics.
\end{abstract}

\section{RESUMO}

Objetivo: Compreender as estratégias de resistência adotadas pelos estudantes de graduação em enfermagem, diante de situações de sofrimento moral (SM). Método: Pesquisa qualitativa, desenvolvida em três universidades do sul do Brasil, duas federais e uma privada, com 21 estudantes de graduação em enfermagem, entre dezembro de 2015 e fevereiro de 2016; os dados foram submetidos à análise textual discursiva e referencial teórico foucaultiano. Resultados: Os estudantes ao resistirem demonstram um senso de autopreservação e fortalecimento moral. Ainda, ações de não resistência relacionam-se ao medo de possíveis sanções. Assim, ao resistir ou não, os estudantes podem vivenciar repercussões tanto positivas como negativas. Considerações finais: Ao resistir, os estudantes visam defender o que acreditam ser o correto, demonstrando seu fortalecimento moral diante do sofrimento moral. No entanto, o exercício do poder disciplinar parece contribuir para sua fragilização moral, dificultando a implementação de estratégias de resistência.

Descritores: Estudantes de Enfermagem; Educação em Enfermagem; Poder; Moral; Ética.

\section{RESUMEN}

Objetivo: Comprender las estrategias de resistencia adoptadas por los estudiantes de graduación en enfermería, ante situaciones de sufrimiento moral (SM). Método: La investigación cualitativa, desarrollada en tres universidades del sur de Brasil, dos públicas y una privada, con 21 estudiantes de graduación en enfermería, entre diciembre de 2015 y febrero de 2016 ; los datos fueron sometidos al análisis textual discursivo y referencial teórico foucaultiano. Resultados: Los estudiantes al resistir demuestran un sentido de autopreservación y fortalecimiento moral. Aún, acciones de no resistencia se relacionan con el temor de posibles sanciones. Así, al resistir, o no, los estudiantes pueden experimentar repercusiones tanto positivas como negativas. Consideraciones finales: Al resistir, los estudiantes pretenden defender lo que creen ser lo correcto, demostrando 
su fortalecimiento moral ante el sufrimiento moral. Sin embargo, el ejercicio del poder disciplinario parece contribuir a su debilidad moral, dificultando la implementación de estrategias de resistencia.

Descriptores: Estudiantes de Enfermería; Educación en Enfermería; El poder; La Moral; La Ética.

\section{INTRODUCTION}

In the context of academic education in nursing, students often experience conflicts and situations that are morally inappropriate, disrespectful of themselves, their colleagues, patients, nursing and health workers, recognizing themselves discouraged, fearful and powerless to react and raise questions and indignation ${ }^{(1-2)}$.

Thus, nursing students experience morally distressing situations and they witness circumstances of care and behavior that are morally inappropriate in the academic environment, disrespect to the subjects and their rights, incompatible with their values, principles and personal standards learned during their academic training, possibly experiencing moral distress (MD). Studies on MD in nursing students have been prominent in the international ${ }^{(1,3-7)}$ and national ${ }^{(8-10)}$ fields.

In this context, students may face difficulties to resist disciplinary mechanisms of power, which aim to form docile bodies with maxims of obedience and submission to norms and hierarchy ${ }^{(11)}$. Thus, the experience of MD by undergraduate students in nursing raises the need to reflect on their academic formation, from Michel Foucault's point of view, such as power, resistance and disciplinary power.

Power is, in a Foucauldian perspective, understood as a multiplicity of relations of forces and resistances and it is present in all human actions and in all their social organizations. Resistance to power must be understood as that which aims at the defense of freedom, constituting a new economy of power relations, in a mobile and transformative way ${ }^{(12)}$. That is why we must say resistances are always changeable. Disciplinary power, easily adopted in institutions, such as university, aims at disciplining, normalizing and maintaining hierarchical models ${ }^{(13)}$. Moreover, disciplinary techniques can lead students to fear repression, favoring their strict compliance with instructions and, under the eyes of supervisors, weaken their capacity for moral and ethical judgment ${ }^{(14-15)}$.

Therefore, teaching becomes a training ${ }^{(16)}$ and moral distress is a possibility before the many ethical conflicts experienced by students in university, since, contradictorily, their apparent omission and indifference to these situations, also causes them feelings of suffering recognized as $\mathrm{MD}^{(16)}$.

Nursing students may have attitudes of coping with morally inappropriate situations, through acts of resistance, that is, a relation of forces, action, reaction and persistence, constituting a possibility of response to $M D^{(6,11)}$. Thus, in the face of disciplinary power, resistance exercise requires nursing students the courage to fight for what they believe to be ethical and moral in the situations that generate $M D$, demonstrating their moral strengthening.

Given that, seeking to understand the issues surrounding the phenomenon of MD in Brazilian nursing students, the following research question emerged: How have students been resisting morally inappropriate situations in the academic environment?

\section{OBJECTIVE}

To understand the resistance strategies adopted by undergraduate students in nursing, faced with situations of moral suffering (MD).

\section{METHOD}

\section{Ethical Aspects}

The ethical and scientific requirements recommended for research with human beings were assured through Resolution 466/2012, and the project was approved by the Research Ethics Committee of the Federal University of Rio Grande. We decided to identify the universities studied by the letter $U$ followed by one $(U 1, \cup 2$ and $U 3)$, and the statements of students with the letter $\mathrm{E}$ (E1 to $\mathrm{E} 21$ ) followed by a sequential number.

\section{Type of Study}

Qualitative, exploratory, descriptive research.

\section{Methodological processes}

\section{Research Scenario}

The study was developed in three universities from the south of Brazil -two public and one private. At U1 public university, the Undergraduate Nursing Course has 41 years of activity and the curriculum is developed under subjects, with a total workload of 4,110 hours, in ten semesters. At U2 public university, the Undergraduate Nursing Course has 40 years of activity and the curriculum is structured in active learning teaching methodologies, in cycles distributed over five years, with a total course load of 5,187 hours. In the U3 private university, the Undergraduate Nursing Course has 10 years of activity and the curriculum is developed under disciplines, with a total workload of 4,000 hours, in ten semesters.

\section{Data sources}

In the previous stage of this research, through the implementation of the Moral Distress Scale (MDS) in Nursing Students, to measure the frequency and intensity of $\mathrm{MD}$ in undergraduate nursing students, we invited people to participate in the qualitative step of the study, requesting their e-mail or telephone for later contact. Therefore, the inclusion criteria were restricted to: be an undergraduate nursing student, enrolled within the fifth and the tenth semester, provide their contact in the quantitative instrument and be available to respond to the semi-structured interview guide.

Thus, 134 students were interested; 65 of them were contacted because they were enrolled within the sixth and the tenth semester, considering that they would have experienced a greater range of situations triggering MD during their academic training. The group of respondents comprised 21 students who returned the researcher's contacts (eight students from $\mathrm{U} 1$, five from $\mathrm{U} 2$ and eight from $\mathrm{U} 3$ ). 


\section{Data collection and organization}

Data collection was performed from December 2015 to February 2016, in different places and times, indicated according to the preference of the participants. Semistructured, recorded interviews with an average duration of 45 minutes, containing closed questions, to characterize the participants, and open questions, focused on aspects related to the experience of MD, strategies developed to resist MD, barriers, facilitators and possible implications of this confrontation.

\section{Analysis of results}

The data was analyzed under the concepts of power, resistance and disciplinary power of Foucault, through discursive textual analysis, understood as a self-organized process to develop comprehension, in which new understandings emerge from a recursive sequence of three components: unitarization, the establishment of relations and the capture of the new emergent ${ }^{(17)}$. During the categorization, relations between the units of meaning were identified, comparing them and grouping close meanings into intermediate categories, and then into final categories.

As for elaborating and creating the resistance actions referred to by the nursing students, their difficulties of exerting resistance in the academic context were also evidenced, demonstrated through behaviors of non-resistance in the face of morally inadequate situations that generate MD. Thus, from the analysis of the data, two categories emerged. 1) Strategies of resistance to MD: exercise of power; and 2) The non-resistance to MD: the disciplinary power in the moral fragilization of students, according to Figure 1.

\section{RESULTS}

Characterizing 21 nursing students interviewed showed that their ages varied between 21 and 50 years; 19 were women; 13 students from federal universities; mostly enrolled in the tenth semester (6), followed by the eighth semester (5); seven never failed in any subject and six once failed.Most of them were single, white, Catholic, did not work; three work in the health area. Besides that, seven students reported previous training as nursing techniques.

Strategies of Resistance to Moral Distress: Exercise of Power Nursing students seem to develop resistance strategies that differ according to their university. Thus, at the U2 federal university, they have demonstrated, differently, the sense of self-preservation in the exercise of their autonomy and freedom when using strategies of resistance, from the analysis of relations of force in which they are immersed, defending personal values and principles.

I thought that if I could act and change something, I would do it. Now, when I saw it was something static I asked to change the institution of my internship because I could not stay there, I suffered [...] and could not apply what I have learned. (U2/E13)

In the public institution $U 1$, the strategy of resistance that stood out was dialogue (faced with situations considered morally inadequate) especially when students realized they had more mastery of nursing knowledge and, therefore, with greater security and confidence to carry out confrontations, proving their moral strengthening.

I interrupted the nursing consultation and asked my professor to leave the room because she was screaming at the patient. [...] I asked it because I knew that this was not a way to treat the patient and she had the right to be cared for in the best way. In that same day, we met with the professor to talk about this situation. (U1 / E1)

At first, I did nothing to defend my colleague, but with time and the continuity of verbal abuse, it became increasingly difficult to live with this situation. So, I went to talk to the professor and then to my colleague, I had to do something, I could not bear it anymore. Even my husband supported me after I told him. (U1 / E7) 
At the U3 private university, students used intervention mechanisms through professor evaluation and the use of course coordination, as resistance strategies motivated by a sense of self-preservation when they perceived the transgression of moral values and principles.

The professor was a pharmacist and was not patient to explain the subject because we were nursing students. But she was being paid to teach us and we wanted to learn. In this situation, I was too scared to flunk, because I work to pay for college and I knew I could not pay it again, so I sought coordination to complain. We're paying to have education; even if it was in a public university, anyway, you pay your taxes to get it. (U3 / E20)

I make a point of answering the evaluation about professors that the university offers in the system. (U3 / E21)

Thus, it was possible to identify manifestations of resistance among nursing students of the three institutions through persistent and autonomous manifestations in defense of what they believe, regardless of the possibility of suffering sanctions, proving their courage to advocate for themselves and for others.

I told the professor: I don't have to be the way you want me to be, I will never have a personality that someone else wants. I am this person, and that's why I will never stop asking and questioning when I don't agree with something. (U1 / E6)

I wanted to participate in this research because I needed to talk, to tell someone. This is one way to deal with this situation. (U2 / E12)

The nurse lectured me because she thought I wasted a lot of time talking to patients; I said that I believe it is important to talk to them; but she told me to change and be objective. I didn't change, I knew I was doing the right thing, [...] I felt that the problem was hers, that I had to be stronger because I was doing it right. She lowered my grades, but it doesn't mean the world to me, the grades. (U3 / E16)

However, resistance strategies can negatively affect those involved: students, professors and users.

We tried to intervene to provide the appropriate nursing care to the humanized childbirth, but the physician seemed to perform a patient analgesia a little higher than needed, which we concluded in the stage group; perhaps, to prevent the patient from doing other procedures and not bother the staff. (U1 / E4)

When I talked to the professor, she said, "Do not bother me, I can harm you" ... I cannot remember the exact words, but that was her attitude, "do not defend your colleague because otherwise you will harm yourself too". (U1 / E7)

In anatomy classes, she gave one subject and a different one was on the exam. The group got together to go to the coordinator and the ombudsman to complain; some colleagues sued the university and the professor was fired. (U3 / E14)

Most of the 21 students, however, also rated the consequences of their resistance exercise as positive.
The professor brought the class together, admitted that she had made a mistake and apologized. And told us never to act like that. (U1 / E1)

It felt good to have spoken and the nurse listened to me even though I did not change her decision, she realized that someone else thinks differently and speaks. I think this is good, because sometimes the professionals disagree with the attitude of others and do not say anything, in a level that the technicians came to tell me that I had said everything they also wanted to say. (U2 / E9)

When we talked to the professor she welcomed us, it was not so bad, the group said what they thought, she listened, she apologized and said that it would not happen again. (U3 / E18)

Nevertheless, the search for an understanding of the phenomenon of resistance to MD in the academic environment is also related to the difficulties that nursing students face to elaborate and strengthen these attitudes of resistance, evidenced through non-resistance.

\section{The non-resistance to Moral Distress: the disciplinary power in the moral fragilization of students}

The exercise of disciplinary power through disciplinary mechanisms (e.g., the emphasis on normalization and obedience to hierarchy) motivates non-resistance, especially due to the fear of disciplinary punishment present among nursing students.

We identified differences among students of three universities about non-resistance. In the U1 public institution, most of the students found moral and ethical problems in their relation with nursing professors, through authoritarian teaching practices that hindered the expression of their self, contributing to their denial, knowledge, desires, values, which negates their subject condition. Non-resistance, for them, is as an attitude of self-preservation, based on a constant sense of fear, to preserve their image and the possibility of suffering sanctions.

I did not say anything, because unfortunately I'm afraid of the Nursing faculty group, it's pure gossip, everybody knows about everyone's life. So they get a bad image of people who speak up, a bias, and it makes students look bad. (U1 / E1)

The professor gives the orders. The professor decides your grades during internship.[...] I was afraid to speak, mainly because of my grades; so I did what my professor ordered, even though I did not agree, I did nothing for fear of being disapproved. I have never flunked, and I believe it is because of many things I did not say, many things I did not face. (U1 / E5)

In both U2 public university and U3 private university, students showed that power relations experienced in the academic and health environment often seem to strengthen and reproduce the normalization of health practices and hegemonies. It makes difficult to exercise resistance to morally inadequate situations.

Our professor did not advise us to get close to certain patients. We couldn't even check their vital signs because they were the doctor's responsibility and we weren't allowed to examine 
them, only medical students were. It bothered me, I wanted to assist everyone, but the professor wasn't willing to support us and lose the internship field [...]. The same situation happened in another semester with my supervisor [a nurse]. She also said the same things and I replied: "I already know how it is." (U2 / E10)

In the health unit we were under internship there wasn't a room for nursing students, only for medical students. We could only visit patients when medical students didn't go. We first complained to professors, then we went in the coordination, but they said it was the same, that medicine needed more input and infrastructure. There were also fellow nursing technicians who also found this normal. (U3 / E17)

Moreover, we could also identify that students from the three universities had problems to resist due to a perception of themselves, their inability to act with sufficient autonomy and confidence. This was either by lack of knowledge and/or (in) experience, normalizing a profile still built to obey established hierarchies and norms, as part of a body of knowledge.

When my professor yelled at me, I wanted to say that I didn't know how to do it, I had never done, but I had no reaction. I couldn't answer her back, I am a student, I must respect her [...], especially at the beginning of graduation, when we don't know much; so I was quiet to avoid more controversy or discussion. (U1 / E2)

How would I tell the teacher that I did not agree? [...] professors are always right, and we can't say the same about students. [...] What am I? Only a graduate student, nobody special. (U2 / E12)

We don't have the autonomy to face doctors, [...] if they insult us, how would we respond? We felt very humiliated... our hands are tied because we are students and can't do anything, doctors give the orders, not us. (U3 / E20)

Strengthening individualism, omission and conformism are possibilities for students to survive MD, in an apparent renunciation of their values and those of their future profession. On the other hand, avoiding defense and, consequently, compromising the ethical dimension of care to users.

It's bad not to talk, because you hurt your patient, but nobody said anything, did anything. I also was not going to do it [...] and I was afraid of losing the internship field experience. (U1/E2)

When the professor accused my colleague, she was wrong, but if I had defended him, I would create myself a problem, so he should defend himself. (U2 / E11)

Medicine professionals didn't respect the patient, but I kept quiet because I wouldn't fight alone; in the end, things just don't change. (U3 / E15)

Moreover, non-resistance and the repercussions referred to have shown that students daily live in a solitary and silent way. It is a process of suffering, including physical changes, when they do not act according to what they believe, regardless if it is a public or private university.
In practical evaluations, students would leave crying, due to the pressure put by professors. It was so traumatic that many colleagues made basic mistakes because they were nervous and anxious; they were trembling, they had stomach pains and they went through all this alone. (U1 / E4)

During the internship in the health center, it was a daily stress. The nurse told me to do things that did not have academic content, but I did everything. In addition, I've faced difficult moments during undergraduate course and never talked about them. I had a crisis at the end of the eighth semester, a fatigue with chest pain during the internship [...], I took an intravenous analgesic, and yet my fibromyalgia got worse. (U2 / E11)

The teacher lectured me in front of the patient, saying: you must act like I do and not the way you think it is right. I suffered, I didn't want to go to classes or the internship, I wanted to stop university. (U3 / E14)

\section{DISCUSSION}

Most of nursing students were from public universities, enrolled in the last semesters of nursing graduation, which may be related to a great experience of situations which were morally inadequate in the academic environment. Nursing students told different coping strategies to situations considered morally inadequate, which caused MD, contemplating attitudes of resistance or not, and, consequently, experiencing different repercussions. For this, when experiencing relations of power, present in an undesirable situation, the student may or may not feel able to face it ${ }^{(18)}$.

For Foucault, one of the meanings of the word "strategy" is to define how, in a game of power, the player acts based on their thinking about the performance of others and how others believe they will act ${ }^{(13)}$. "There is no real place of resistance, but movable and transitory points that are distributed throughout social structure"(19).

The first category showed strategies of resistance to MD used by nursing students, as an exercise of power, guided by a sense of self-preservation and moral strengthening, through intervention mechanisms, with possible negative and positive repercussions.

Nursing students from U2 university created resistance strategies based on self-preservation. They were related to intervention mechanisms such as the change of the internship field, motivated by autonomy and freedom ideas to resist ethically questionable practices. This was an attempt to preserve values and principles, avoiding compliance with the established. In U1, the students used dialogue with professors about the situations they considered morally inadequate, to modify authoritarian teaching practices. Students from U3 private university, talked to the coordination of the nursing course and filled in the teaching evaluation to protect their interests, maintaining their financial investment.

Students resisted to defend their process of learning and evaluation, despite possible sanctions in the academic hierarchy. Thus, struggles of resistance, in the case of normalization, are struggles for autonomy and emancipation. For this, they demand continuous and uninterrupted work to confront disciplinary mechanisms against techniques of individuation. Having a critical attitude is a form of resistance that is not caused by violence, but by a change of attitude toward power ${ }^{(12-13,15)}$. We saw similar 
results in another study, in which a nursing student adopted a confrontation and resistance posture in front of their internship supervisor. This student did not allow the violation of the user's rights to receive quality care, and thus their own ideals ${ }^{(6)}$.

We also verified that the more knowledge students consider they have, the more they feel confident to persist and resist to defend what they believe to be correct. This is the courage and autonomy to advocate for themselves and others, which demonstrates moral strengthening of nursing students. Such strategies associate exercise of power with moral strengthening of students to defend themselves and others in the academic environment. Similarly, the justification for nursing students to resist is related to the influence of their role as speakers of patients ${ }^{(20)}$, a role that should be strongly encouraged in their training. This would strengthen resistance strategies. Ethical judgments must be conducted to exercise speaking for people, whether for patients or colleagues, which implies questioning and confronting established values, norms and practices. That is a guarantee for respect for those involved ${ }^{(21)}$.

As a result, resistance actions can have negative repercussions for all people involved: professors, users and students. Thus, sanctions as: threatening and reprising students; firing professors and giving careless assistance to users are common. Such situations demonstrate that students defending themselves and others implies a positioning that generally creates risks and conflicts, since it unbalances power relations ${ }^{(22)}$. Moreover, the difficulty to exercise power and establish resistance points in power relations can also generate $\mathrm{MD}^{(22)}$.

Positive repercussions were also evidenced by most of students who resisted, such as their moral empowerment through the exercise of power, the apology of professors, and recognition of the health team. Thus, the actions of students may be directly related to MD intensity, since those who resist MD minorities, while those who have expressed regret for not having resisted refer to experiencing more MD situations ${ }^{(18)}$. On the other hand, the possible repercussions of resistance actions, like punishments and retaliations without reaching the desired ruptures, can increase students' suffering.

Therefore, in a seemingly contradictory way, the sense of self-preservation that students showed in this study can be justifications either to resistance or non-resistance. When nursing students do not resist it is related to the fear of punishment and sanctions, resulting in a negative evaluation, with lower grades, disapproval, humiliation and/or losses of opportunities for students to develop their knowledge.

Disciplinary mechanisms derived from disciplinary power are related to the non-resistance of nursing students, understood as strategy of survival to the MD. The disciplinary power in U1 public university was evidenced through authoritarian educational behavior, which apparently aims to shape and normalize the conduct of students. Relations of power and, consequently, MD experienced by students in public U2 and private university U3, seemed more associated with their discouragement to defend what they believe, strengthening hegemonies and professional hierarchies.

Disciplinary power is as a mechanism of control in the academic context, by dominating the bodies of individuals, to make them governable. Thus, discipline and its sanctions allow the exercise of disciplinary power to continue over individuals and a greater coercive control over their attitudes ${ }^{(15,19)}$, influencing the perception of powerlessness in students and, consequently, inaction as an option of $\mathrm{MD}^{(1)}$.

Initially, students said they recognize themselves with little knowledge and autonomy in the academic environment, which made them fear resisting MD, due to possible sanctions seen as small punishments to penalize actions that do not fit into the norms. This would be a loss in the evaluation process and a restriction of opportunities. These perceptions corroborate with international studies that cite the lack of confidence in a complete understanding of the situation, related to the inexperience and/ or lack of knowledge and to the performance of a subordinate role in the team ${ }^{(1-2)}$, as justification for actions of not resistance.

The position students claim to have in the academic hierarchy is recognized as inferior, favoring their perception of frailty and impotence in a power relations game, despite its moral implications. Likewise, in other studies, students attributed their inaction to the lack of a professional model, realizing that their instructors seemed to tolerate or perpetuate certain unethical situations, which seemed to absolve them of a sense of responsibility ${ }^{(1-2)}$.

Nursing students seem to have renounced their own values, resigning themselves to the normalization diffused in the academic environment as a strategy of self-preservation faced with the possibility of suffering sanctions. When they witness situations that are morally inadequate, they opt for resignation to maintain learning opportunities, behaviors that morally weaken them. In contrast, the apparent omission and indifference to these situations may increase their perception of $\mathrm{MD}^{(16,22)}$.

Hence, the repercussions of inaction seem to relate predominantly to students, and in a negative way, with guilt and intensification of suffering. According to another study, students individually and quietly faced contradictory situations because of limited opportunities to discuss moral and ethical issues with supervisors/professors ${ }^{(23)}$. Thus, after repeated expositions to negative examples, students who condemn a certain act may come to accept them ${ }^{(23)}$.

Disciplinary power in the formation of docile bodies seems to inhibit decision-making processes that result in acts of resistance, by creating passive students. Furthermore, it contributes to the moral fragilization of students, by an acceptable, and therefore normalizing, practice of omission before morally inadequate situations, not exercising the defense of users and colleagues. Thus, nursing graduation, besides teaching to care, seems to teach to silence and to exile before the careless of the users. This fact raises the concern that students demonstrate a certain degree of regression of moral development during clinical training, rather than moral growth ${ }^{(18)}$.

Encouraging attitudes of resistance and articulating power between individuals is more beneficial to confront MD for those involved than just assuming a passive role ${ }^{(24)}$. Students must overcome inertia, often demonstrated, to change work environments and academic training, through the exercise of power; preferably, through a collective resistance to these situations that are a response to $\mathrm{MD}^{(24)}$ by speaking and fighting inside and outside the institutions. The response to inaction is activism ${ }^{(16)}$. 


\section{Study limitations}

The period of data collection was reduced, and we often waited for the end of university holidays. However, the interest shown by the 21 students in participating is possibly related to their intense experiences of MD. This may have influenced their need to share experiences, even as a way of coping with the situations that create them.

\section{Contributions to the nursing, health or public policy sectors}

Regardless of whether the university is public or private, nursing students experience situations that generate MD in the academic environment, requiring their confrontation. Therefore, the attitudes of resistance to MD assumed by students may not only contribute to reorganizing teaching and health contexts in favor of an academic formation and a service delivery based on respect and ethics, but will also contribute to their own formation and moral strengthening .It is the practice of freedom that gains positivity and enables creating new contexts, through the rupture with traditional power relations, considered normal and acceptable.

\section{FINAL CONSIDERATIONS}

Resistance strategies adopted by nursing students, through their exercise of power, are intensified with the expansion of the mastery of knowledge by students. They feel more confident with the perception of greater autonomy and freedom in defense of what they believe and moral empowerment before morally inadequate situations.

However, the exercise of disciplinary power seems to contribute to their moral fragilization, making it difficult to implement resistance strategies to MD. Hence, we question: if nursing training morally weakens students, how will they become confident professionals to resist before morally questionable situations?

Resisting or not creates possibilities of repercussions before $M D$, both positive and negative, influencing students in the decision to present their opinions. They consider, first, the possibility of suffering sanctions, a fact that often causes nonresistance, as a strategy that may cause them less suffering. However, this behavior may result in attitudes of disbelief of ideals, and, consequently, of the profession.

\section{FUNDING}

Study conducted under the research project "Speaking for patients and coping in nursing: possibilities of exercising power through experiences of moral distress", financed by Universal Call 14/2012 (case 474761 / 2012-6). Research was also supported by a PhD grant awarded by the Foundation for Research Support of the State of Rio Grande do Sul (Fundação de Amparo à Pesquisa do Estado do Rio Grande do Sul - FAPERGS), from 2013 to 2016.

\section{REFERENCES}

1. Wojtowicz B, Hagen B, Daalen-Smith CV. No place to turn: nursing students' experiences of moral distress in mental health settings. Int J Ment Health Nurs[Internet]. 2014[cited 2016 Jun 13];23(3):257-64. Available from: https://www.ncbi.nlm.nih.gov/ pubmed/23980930

2. Wiggleton C, Petrusa E, Loomis K, Tarpley J, Tarpley M, O'Gorman ML, et al. Medical students' experiences of moral distress: development of a web-based survey. Acad Med[Internet]. 2010[cited 2016 Apr 13];85(1):111-7. Available from: https://www.ncbi. nlm.nih.gov/pubmed/20042836

3. Theobald A. Moral distress in baccalaureate nursing students. Ky Nurse[Internet]. 2013[cited 2016 Jul 1];61(2):5-6. Available from: https://www.ncbi.nlm.nih.gov/pubmed/23617179

4. Escolar-Chua RL. Moral sensitivity, moral distress, and moral courage among baccalaureate Filipino nursing students. Nurs Ethics[Internet]. 2016 [cited 2018 Feb 7];e-0969733016654317. Available from: http://journals.sagepub.com/doi/pdf/10.1177/0969733016654317

5. Curtis K. Learning the requirements for compassionate practice: student vulnerability and courage. Nurs Ethics[Internet]. 2014[cited 2016 Aug 7];21(2):210-23. Available from: http://nej.sagepub.com.ez40.periodicos.capes.gov.br/content/21/2/210.long

6. Grady A. Experiencing moral distress as a student nurse. Imprint [Internet]. 2014[cited 2016 Sep 5];61(2):40-2. Available from: https://www.ncbi.nlm.nih.gov/pubmed/24707639

7. Rees CE, Monrouxe LV, Mcdonald LA. 'My mentor kicked a dying woman' sbed...' Analysing UK nursing students' 'mostmemorable' professionalism dilemmas. J Adv Nurs[Internet]. 2015[cited 2016 Jun 20];71(1):169-80. Available from: http://onlinelibrary-wileycom.ez40.periodicos.capes.gov.br/doi/10.1111/jan.12457/epdf

8. Bordignon SS, Lunardi VL, Barlem ELD, Lunardi Filho WD, Tomaschewski-Barlem JG, Ramos AM. Moral distress among undergraduate nursing students who question the choice of professional career. J Nurs Soc Health[Internet]. 2014[cited 2016 Sep 11];1(1):63-9. Available from: http://dx.doi.org/10.15696/2358-9884/jonse.v1n1p63-69

9. Renno HMS, Brito MJM, Ramos FRS. Estágio curricular e o sofrimento moral do estudante de enfermagem. Enferm Foco[Internet]. 2015[cited 2016 Sep 13];6(1/4):51-5. Available from: http://revista.portalcofen.gov.br/index.php/enfermagem/article/viewFile/577/259

10. Renno H M, Ramos FR, Brito MJ. Moral distress of nursing undergraduates: myth or reality? Nurs Ethics[Internet]. 2016 [cited 2016 Nov 1];e0969733016643862. Available from: http://journals.sagepub.com/doi/abs/10.1177/0969733016643862

11. Lunardi VL. Medo: fio visível/invisível na docilização do corpo da enfermeira. Rev Bras Enferm [Internet]. 1995 [cited 2016 Aug 17];48(3):195-203. Available from: http://www.scielo.br/pdf/reben/v48n3/v48n3a02.pdf 
12. Foucault M. Ditos e Escritos IV: estratégias, poder/saber. 3 ed. Rio de Janeiro: Forense Universitária, 2012.

13. Castro E. Vocabulário de Foucault. Belo Horizonte: Autêntica Editora, 2009

14. Sasso L, Bagnasco A, Bianchi M, Bressan V, Carneval F. Moral distress in undergraduate nursing students: a systematic review. Nurs Ethics[internet]. 2015[cited 2017 Dec 21];23(5):523-34. Available from:http://dx.doi.org/10.1177/0969733015574926

15. Foucault M. Vigiar e Punir: nascimento da prisão. 42. ed. Petrópolis, RJ: Vozes; 2015.

16. Jameton A. A reflection of moral distress in nursing together with a current application of the concept. J Bioeth Inq[Internet]. 2013[cited 2016 Oct 10];10(3):297-308. Available from: https://dx.doi.org/10.1007/s11673-013-9466-3

17. Moraes R, Galiazzi MC. Análise textual discursiva. 2. ed. rev. Ijuí: Ed. Unijuí; 2013.

18. Lomis KD, Carpenter RO, Miller BM. Moral distress in the third year of medical school; a descriptive review of student case reflections. Am Surg[Internet]. 2009[cited 2016 Jun 10];197(1):107-12. Available from: https://www.ncbi.nlm.nih.gov/pubmed/19101252

19. Machado R. Por uma genealogia do poder. In: Foucault M. Microfísica do poder. 26. ed. São Paulo: Graal; 2008.

20. Wright A, Hawkes G, Baker B, Lindqvist M. Reflections and unprompted observations by health care students of an interprofessionals hadowing visit. J Interprof Care[Internet]. 2012[cited 2016 Jun 13];26(4):305-11. Available from: http://www.tandfonline.com/doi/ full/10.3109/13561820.2012.678507

21. Tomaschewski-Barlem JG, Lunardi VL, Barlem ELD, Ramos AM, Silveira RS, Vargas MAO. Como enfermeiros vêm exercendo a advocacia do paciente no contexto hospitalar? uma perspectiva foucaultiana. Texto Contexto Enferm [Internet]. 2016 [cited 2016 Jul 10];25(1):e2560014. Available from: http://www.scielo.br/pdf/tce/v25n1/0104-0707-tce-25-01-2560014.pdf

22. Krautscheid L, DeMeester DA, Orton V, Smith A, Livingston C, McLennon SM. Moral distress and associated factors among baccalaureate nursing students: a multisite descriptive study. Nurs Educ Perspect[Internet]. 2017[cited 2018 Feb 06];38(6):313-9. Available from: https://www.ncbi.nlm.nih.gov/pubmed/28926501

23. Hilliard RI, Harrison C, Madden S. Ethical conflicts and moral distress experienced by paediatric residents during their training. J Paediatr Child Health[Internet]. 2007[cited 2016 Sep 10];12(1):29-35. Available from: https://www.ncbi.nlm.nih.gov/pmc/articles/ pmid/19030336/

24. Lunardi VL. Moral distress: an innovative and important subject of study in Brazil. J Bioeth Inq [Internet]. 2013 [cited 2016 Jun 5];10(3):309-12. Available from: https://dx.doi.org/10.1007/s11673-013-9458-3 